\title{
PENERAPANMODIFIED INQUIRY MODELS UNTUK MENCEGAHMISKONSEPSISISWA PADA KONSEP KESETIMBANGAN KIMIA
}

\author{
Arif Imam Subagyo ${ }^{1)}$ \\ Suyono ${ }^{2)}$ \\ Tukiran ${ }^{3)}$ \\ ${ }^{1)}$ Gurudi SMA Negeri 10 Samarinda Kalimantan Timur \\ ${ }^{2)}$ Dosen Prodi Pend. Sains PPs Universitas Negeri Surabaya \\ ${ }^{3)}$ Dosen Prodi Pend. Sains PPs Universitas Negeri Surabaya \\ e-mail:arimas246@yahoo.com
}

\begin{abstract}
Abstrak: Penelitian ini bertujuan untuk mencegah miskonsepsi siswa pada konsep kesetimbangan kimia. Pencegahan terjadinya miskonsepsi dilakukan dengan menggunakan model pembelajaran modified inquiry. Sasaran penelitian adalah siswa kelas XI IPA di SMAN Kabuh Kabupaten Jombang.Penelitian ini merupakan penelitian pra-eksperimen dengan one group pretest-posttest design. Identifikasi miskonsepsi menggunakan metode Three Tier Test. Teknik analisis data diskrit menggunakan deskriptif kualitatif dan data kontinyu menggunakan statistik inferensial yaitu: Mann-Whitney Test,t-Test, dan Wilcoxon's Sign Rank Test.Pembelajaran menggunakan modified inquiry berhasil mencegah miskonsepsi siswa dan membuat siswa menjadi tahu konsep, tetapi masih menyisakan beban miskonsepsi siswa. Dengan menggunakan uji statistik inferensial pada taraf kepercayaan 95\% dapat disimpulkan bahwa pada kelas penelitian terjadi penurunan secara signifikan beban miskonsepsi siswa sebagai dampak pembelajaran menggunakan modified inquiry.
\end{abstract}

Kata-kata kunci:modified inquiry, miskonsepsi, kesetimbangan kimia

\begin{abstract}
This research aims prevent student's misconception to the concept of chemical equilibrium. Misconceptions prevention performed was using a modified inquiry model.Subject in this research arestudents science grade XI in SMAN Kabuh Jombang.This research is pre-experiment with one group pretest - posttest design. Identification of misconceptions used Three Tier Test method. The resulted discrete data was analyzed using qualitative descriptive and continu data was analyzed using inferential statistics, namely the Mann-Whitney test, $t$-Test, and Wilcoxon's Sign Rank Test.A modified inquiry learning models successfully preventedstuedent's misconceptionbut still remained the burden of misconceptions. Based on inferential statistical test with thesignificance level of $95 \%$ it can be concluded that the science classes decreased significantly the level of burdenof misconceptions as the impact of learning a modified inquiry models.
\end{abstract}

Keywords:modified inquiry,misconception. chemical equilibrium

\section{PENDAHULUAN}

Tujuan pembelajaran sains termasuk di dalamnya ilmu kimia yang diamanatkan dalam Permendiknas Nomor 22 tahun 2006 tentang Standar Isi adalah untuk memperoleh pengetahuan berupa fakta, konsep, prinsip, hukum, teori melalui kerja ilmiah, oleh karena itu pembelajaran kimia menekankan pada pemberian pengalaman belajar secara langsung melalui penggunaan dan pengembangan keterampilan proses dan sikap ilmiah. Konsep adalah generalisasi faktafakta yang memiliki ciri-ciri yang sama (Ibrahim, 2012). Konsep merupakan dasar bagi proses-proses mental yang lebih tinggi untukmerumuskan prinsipprinsip dan generalisasi (Dahar, 2011).Pengetahuan bukanlah seperangkat fakta-fakta, konsep, dan prinsip yang siap untuk diambil dan diingat. Siswa harus mengkonstruksi pengetahuan tersebut dan memberi makna melalui pengalaman nyata (Sagala, 2012). Siswa yang terlibat dalam kegiatandan bekerjasama dengan orang lain untuk memperoleh konsep-konsep akan membantu mengatasi terjadinya miskonsepsi (Schunk, 2012). Miskonsepsi adalah pemahaman konsep oleh siswa yang tidak sesuai dengan konsep yang benar menurut para ahli (Suparno,2005). Miskonsepsi merupakan penghambat dalam belajar sains, oleh karena itu miskonsepsi sedapat mungkin diperbaiki (Dahar, 2011).

Miskonsepsi siswa dapat diungkapkan dan digantikan dengan konsep yang benar menurut pengertian ilmiah dengan menggunakan model pembelajaran inkuiri (Barthlow, 2011). Penggunaan model inkuiri mempunyai tujuan agar siswa mampu mencari dan menemukan sendiri berbagai jawaban atas persoalan-persoalan yang dihadapinya seperti seorang ilmuan. Siswa diharapkan bekerja dan berpikir seperti seorang ilmuan sehingga memperoleh pemahaman sesuai dengan yang dipahami ilmuan sehingga siswa tidak mengalami miskonsepsi (Sagala, 2012).

Mata pelajaran kimia penuh dengan konsep abstrak yang tidak mudah dipahami kecuali dihubungkan dengan sesuatu dari pengalaman seharihari. Oleh karena itu siswa sering mengalami miskonsepsi pada mata pelajaran kimia (Barke et al., 2009). Konsep kesetimbangan kimia termasuk konsep dasar (basic concepts) yang sangat penting dalam kimia karena memahami konsep kesetimbangan merupakan dasar untuk memahami konsep-konsep kimia yang lain, seperti sifat asam basa, reaksi oksidai-reduksi dan 
kelarutan (Barke et al., 2009).Pada penelitian ini merupakan upaya pencegahan terjadinya miskonsepsi siswa menggunakan modified inquiry.

Tujuan utama dari penelitian ini adalah mengimplementasikan sebuah model solutif untuk mencegah miskonsepsi siswa SMA, khususnya pada konsep kesetimbangan kimia. Masalah utama itu dijawab dengan menjawab pertanyaan-pertanyaan elementer sebagai berikut:

1. Bagaimana prakonsepsi siswa sebelum pencegahan miskonsepsi siswa dengan model pembelajaran modified inquiry pada konsep kesetimbangan kimia?

2. Bagaimana keterlaksanaan sintaks model pencegahan dengan modified inquiry?

3. Bagaimana konsepsi siswa sesudah pencegahan menggunakan model modified inquiry pada konsep kesetimbangan kimia?

4. Bagaimana perubahan hasil belajar siswa sesudah pembelajaran dengan model modified inquiry?

5. Apakah faktor penyebab miskonsepsi siswa pada konsep kesetimbangan kimia?

Indikator ketercapaian tujuan itu disimpulkan berdasarkan data empiris yang diperoleh saat menjawab rumusan masalah tentang penurunan miskonsepsi siswa sesudah pencegahan dengan model pembelajaran modified inquiry pada konsep kesetimbangan kimia.

\section{METODE PENELITIAN}

Penelitian ini merupakan sebuah tindakan pencegahan miskonsepsi siswa pada konsep kesetimbangan kimia. Rancanganpenelitianyaitupra-eksperimen jenis one group pretest-posttest design(Sugiyono, 2012). Penelitian ini dimulai dengan melakukan tes awal (pretest) yangdigunakan untuk mengetahui prakonsepsi siswa dan pembentukan kelompok kooperatif siswa di kelas. Penelitian dilanjutkan dengan pembelajaran modified inquiry dengan materi kesetimbangan kimia. Sesudah pembelajaran modified inquiry dilakukan posttest untuk memetakan konsepsi siswa sesudahpembelajaran modified inquiry.Berdasarkan hasilposttest 1 dilakukan pengelompokan konsepsi siswa yang meliputi tahu konsep (TK), tidak tahu konsep (TTK, dan miskonsepsi (MK1, MK2, dan MK3).

Sasaran penelitian adalah siswa kelas XI IPA 1 dan XI IPA 3.Teknik pengumpulan data yang dilakukan sebagai berikut: (1) Pengamatan, digunakan untuk menilai keterlaksanaan pembelajaran sesuai dengan sintaks yang telah dirancang oleh guru dalam RPP, menilai kompetensi psikomotorik dan afektif siswa, (2) Tes Pemahaman Konsep, dilakukan dalam dua tahap yaitu tes awal (pretest), diberikan sebelum kegiatan belajar mengajar pertemuan pertama, posttest untuk memperoleh data konsepsi siswa setelah tindakan pencegahan dengan menerapkan model pembelajaran modified inquiry, (3) Kuesioner, digunakan untuk mengidentifikasi faktor-faktor penyebab terjadinya miskonsepsi pada siswa setelah diberikanposttest.

Data hasil tes pemahaman konsep siswa dianalisis untuk pengelompokkan siswa ke dalam kelompok tahu konsep (TK), tidak tahu konsep (TTK), dan miskonsepsi (MK). Kriteria pengelompokan siswa tergolong tahu konsep (TK), tidak tahu konsep (TTK), dan miskonsepsi (MK) berdasarkan respon jawaban siswa pada Three Tier Test seperti yang disarankan oleh Arslan et al.(2012). Statistik inferensial digunakan untuk menganalisis data dengan membuat kesimpulan yang berlaku umum.Pengolahan data secara statistik dilakukan dengan menggunakan program SPSS (Statistical Package for Social Science) versi 18.0. Uji statistik yang digunakan dalam penelitian, yaitu: MannWhitney Test, Kolmogorov-Smirnov Test, t-Test, dan Wilcoxon's Signed Rank Test(Djarwanto, 1991; Sudjana. 1996).

\section{HASIL DAN PEMBAHASAN}

\section{A. Prakonsepsi Siswa Sebelum Pencegahan Miskonsepsi Siswa.}

Profil prakonsepsi siswa kelas XI IPA 1 dan XI

IPA 3 yang berupa deskripsi jumlah beban prakonsepsi siswa pada masing-masing konsep kesetimbangan kimia disajikan pada Tabel 1 dan persentase prakonsepsi siswa secara keseluruhan (klasikal) disajikan pada Gambar 1, dan Gambar 2.

Tabel 1 Data Prakonsepsi Siswa pada Konsep Kesetim-bangan Kimia di Kelas XI IPA 1 dan XI IPA 3

\begin{tabular}{|c|c|c|c|c|c|c|c|c|c|c|}
\hline \multirow{3}{*}{$\begin{array}{l}\text { ¿े } \\
\overline{0} \\
\overline{0}\end{array}$} & \multicolumn{5}{|c|}{ Kelas XI IPA 1} & \multicolumn{5}{|c|}{ Kelas XI IPA 3} \\
\hline & \multicolumn{5}{|c|}{ Profil Prakonsepsi } & \multicolumn{5}{|c|}{ Profil Prakonsepsi } \\
\hline & $\because$ & 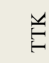 & $\bar{\Sigma}$ & $\ddot{z}$ & $\tilde{z}$ & $\because$ & $\stackrel{\mathscr{E}}{\mathrm{E}}$ & $\bar{\Sigma}$ & $\tilde{z}$ & $\frac{2}{2}$ \\
\hline A & 25 & 42 & 10 & 8 & 43 & 18 & 43 & 14 & 8 & 37 \\
\hline B & 9 & 35 & 3 & 4 & 45 & 9 & 39 & 3 & 4 & 35 \\
\hline $\mathrm{C}$ & 5 & 40 & 1 & 4 & 46 & 8 & 43 & 0 & 4 & 35 \\
\hline D & 4 & 25 & 7 & 0 & 28 & 6 & 28 & 6 & 2 & 18 \\
\hline E & 4 & 21 & 6 & 9 & 24 & 4 & 28 & 6 & 6 & 16 \\
\hline $\mathrm{F}$ & 6 & 29 & 3 & 5 & 21 & 3 & 21 & 2 & 5 & 29 \\
\hline$\sum$ & 53 & 192 & 30 & 30 & 207 & 48 & 202 & 31 & 29 & 170 \\
\hline
\end{tabular}

Keterangan Tabel1:

- Konsep A: Kesetimbangan kimia (definisi).

- Konsep B: Hukum kesetimbangan kimia.

- Konsep C: Kesetimbangan homogen dan heterogen.

- Konsep D: Pengaruh perubahan konsentrasi pada arah pergeseran kesetimbangan kimia.

- Konsep E: Pengaruh perubahan tekanan dan volum. pada arah pergeseran kesetimbangan kimia

- Konsep F: Pengaruh perubahan suhu pada arah pergeseran kesetimbangan kimia. 


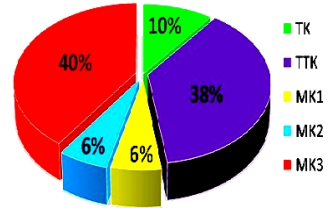

Gambar 1 Diagram Pastel Prakonsepsi Siswa pada Konsep Kesetimbangan Kimia di Kelas XI IPA

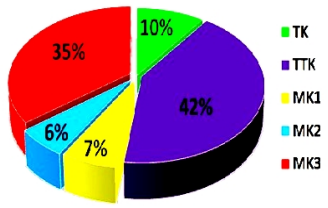

Gambar 2 Diagram Pastel Prakonsepsi Siswa pada Konsep Kesetimbangan Kimia di Kelas
XI IPA 3
Prakonsepsi siswa menunjukkan bahwa siswa berpotensi mengalami miskonsepsi. Fenomena terjadinya miskonsepsi pada prakonsepsi siswa sesuai dengan pernyataan Suparno (2005) bahwa prakonsepsi siswa mengalami kesalahan karena prakonsepsi dibentuk sebelum siswa mendapatkan pelajaran formal tentang konsepyang dimaksud.Siswa mengasosisasikan keadaan kesetimbangan dengan fenomena yang sudah dikenal siswa dalam kehidupan sehari-hari.Sebagai contoh, siswa yang belum diajarkan tentang kesetimbangan, tetapi siswa telah mengonstruksi sendiri bahwa reaksi yang setimbang memiliki massa yang sama.Jika konsepsi siswa sebagai hasil konstruksi tentang alam sekitarnya berbeda(dengan konsepsi ilmiah, maka dikatakan siswa mengalami miskonsepsi (Dahar, 2011).Oleh karena itu, perlu dilakukan tindakan pencegahan terjadinya miskonsepsi.Profil prakonsepsi masing-masing siswa dijadikan bahan pertimbangan untuk pengelolaan pembelajaran yang akan dilakukan, seperti pembentukan kelompok belajar yang akan dibangun saat melaksanakan sintaks dari sebuah model pembelajaran yang dipilih. Pembelajaran kelompok memberi kesempatan kepada siswa untuk terlibat dalam kegiatandan bekerjasamadengan orang dalam memperoleh konsep-konsep sehingga dapat mencegah terjadinya miskonsepsi (Schunk, 2012).

\section{B. Keterlaksanaan Sintaks Model Pencegahan Dengan Modified Inquiry}

Keterlaksanaan pembelajaran di dalam penelitian ini diamati oleh dua orang pengamat (observer). Aspek yang diamati terbagi ke dalam tiga bagian,yaitu:keterlaksanaan sintaks yang terskenariokan dalam RPP, aktivitas siswa, dan penilaian terhadap isian Lembar Kerja Siswa (LKS).Rata-rata hasil pengamatan keterlaksanaan pembelajaran secara keseluruhan pada setiap kelas termasuk ke dalam kategori sangat baik.Hasil uji Mann-Whitney yang membandingkan skorskor penilain sintakspada kedua pengamat dan untuk menilai konsistensi menjaga kualitas pembelajaran pada dua kelas penelitian yang berbeda diperoleh nilai $\mathrm{p}$ value $>0,05$. Artinya, tidak ada perbedaan signifikan atas penilaian keterlaksa-naan sintaks pada setiap tatap muka dari kedua pengamat dan peneliti mampu menjaga konsistensi kualitas dalam melaksanakanpembelajaran pada semua kelas penelitian.Komponen sintaks pembelajaran yang dinilai terdiri dari lima kegiatan utama, yaitu pendahuluan, kegiatan inti, penutup, pengelolaan waktu, dan antusiasme. Kegiatan inti dari model pembelajaran modified inquiry meliputi: menjelaskan proses inkuiri, menyajikan masalah, merumuskan hipotesis, melakukan penyelidikan, organisasi data, analisis data, menarik simpulan, dan merefleksikan proses inkuiri (Arends, 2012).

Hasil pengamatan aktivitas siswa yang merepresentasikan keterampilan psikomotorik, perilaku berkarakter, dan keterampilan sosial memperoleh kriteria penilaian sangat baik di kedua kelas penelitian. Aktivitas siswa yang baik selama pelaksanaan sintaks pembela-jaran membantu siswa untuk lebih mudah memahami suatu konsep yang sedang dipelajari (Forgaty, 1991). Selain itu, belajar bersama dalam kelompok yang diwarnai hubungan sosial dan karakter yang baik akan berdampak positif bagi kemajuan belajar siswa (Vygotsky dalam Arends, 1991).

Hasil penilaian terhadap isian Lembar Kerja Siswa (LKS) hampir semua kelompok menunjukkan tanda-tanda kinerja yang positif pada komponenkomponen yang dinilai. Artinya skenario pembelajaran modified inquiry yang dibantu perangkat LKS telah berhasil mengkondisikan siswa untuk berlatih dan mencapai kinerja proses sains yang baik.

Sintaks model pembelajaran yang dilaksanakanya dengan sangat baik, yang di dalamnya diintegrasikan keterampilan psikomotorik, perilaku berkarakter, dan keterampilan sosialakan menjadikan pembelajaran lebih bermakna. Pembelajaran yang bermakna akan mengha-silkan pemahaman konsepkonsep kesetimbangan kimia yang utuh, dipahami secara baik, tidak mudah dilupakan, dan mencegah terjadinya miskonsepsi siswa.

\section{Konsepsi Siswa Sesudah Pencegahan Miskonspsi Siswa}

Profil konsepsi siswa kelas XI IPA 1 dan XI IPA 3 yang berupa deskripsi jumlah beban konsepsi siswa pada masing-masing konsep kesetimbangan kimia disajikan pada Tabel 2 dan persentase konsepsi siswa secara klasikal disajikan pada Gambar 3 dan Gambar 4.Pembelajaran dengan model pembelajaranmodified inquiry dilakukan untuk mencegah terjadinya miskonsepsi siswa. Profil konsepsi siswa setelah pembelajaran menunjukan bahwa jumlah tahu konsep lebih banyak dibandingkan dengan beban miskonsepsi baik pada status MK1, MK2, maupun MK3 (Gambar 3 dan Gambar 4) sebagai dampak pelaksanaan pembelajaran dengan model pembelajaran modified inquiry. 
Tabel 2 Data Konsepsi Siswa Setelah Pencegahan pada Konsep Kesetimbangan Kimia di Kelas XI IPA 1 dan XI IPA 3

\begin{tabular}{|c|c|c|c|c|c|c|c|c|c|c|}
\hline \multirow{3}{*}{$\begin{array}{l}\text { 口े } \\
\overline{0} \\
\stackrel{0}{0}\end{array}$} & \multicolumn{5}{|c|}{ Kelas XI IPA 1} & \multicolumn{5}{|c|}{ Kelas XI IPA 3} \\
\hline & \multicolumn{5}{|c|}{ Profil Konsepsi } & \multicolumn{5}{|c|}{ Profil Konsepsi } \\
\hline & 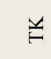 & $\stackrel{ }{E}$ & $\bar{z}$ & $\stackrel{\tilde{v}}{\Sigma}$ & $\stackrel{n}{\Sigma}$ & $\ddot{*}$ & $\stackrel{\mathscr{E}}{\mathrm{H}}$ & $\bar{\Xi}$ & $\tilde{z}$ & $\tilde{\Sigma}$ \\
\hline A & 68 & 21 & 3 & 24 & 12 & 43 & 20 & 4 & 17 & 34 \\
\hline B & 65 & 20 & 0 & 7 & 4 & 57 & 7 & 2 & 14 & 10 \\
\hline $\mathrm{C}$ & 61 & 25 & 2 & 7 & 1 & 65 & 9 & 1 & 9 & 6 \\
\hline $\mathrm{D}$ & 25 & 23 & 2 & 5 & 9 & 38 & 9 & 2 & 5 & 6 \\
\hline E & 29 & 19 & 3 & 9 & 4 & 35 & 8 & 7 & 8 & 2 \\
\hline $\mathrm{F}$ & 30 & 17 & 11 & 1 & 5 & 20 & 7 & 15 & 1 & 17 \\
\hline$\sum$ & 278 & 125 & 21 & 53 & 35 & 258 & 60 & 31 & 54 & 75 \\
\hline
\end{tabular}

Keterangan Tabel2:

- Konsep A: Kesetimbangan kimia (definisi)

- Konsep B: Hukum kesetimbangan kimia.

- Konsep C: Kesetimbangan homogen dan heterogen.

- Konsep D: Pengaruh perubahan konsentrasi pada arah pergeseran kesetimbangan kimia.

- Konsep E: Pengaruh perubahan tekanan dan volum. pada arah pergeseran kesetimbangan kimia

- Konsep F: Pengaruh perubahan suhu pada arah pergeseran kesetimbangan kimia.

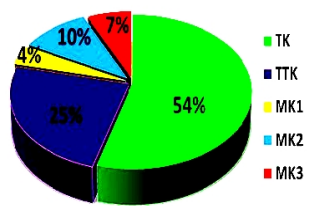

Gambar 3 Diagram Pastel Konsepsi Siswa pada Konsep Kesetimbangan Kimia di Kelas XI IPA 1

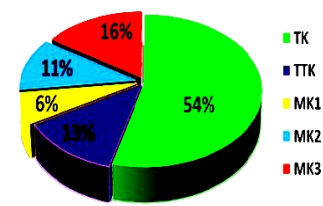

Gambar 4 Diagram Pastel Konsepsi Siswa pad Konsep Kesetimbangan Kimia Kelas XI IPA 3
Fakta ini menunjukkan bahwa pembelajaran konsep kesetimbangan kimia menggunakan model pembelajaranmodified inquiry telah berhasil mencegah terjadinya miskonsepsi siswa yang lebih besar meskipun masih menyisakan siswa yang miskonsepsi.Temuan penelitian ini sejalan dengan pendapat Barthlow (2011), bahwa miskonsepsi siswa dapat diungkapkan dan digantikan dengan konsep yang benar menurut pengertian ilmiah dengan menggunakan model pembelajaran inkuiri.Model pembelajaran yang menggunakan sejumlah keterampilan metodologi ilmiah seperti merumuskan masalah, mengemukakan pertanyaan, melakukan penelitian, analisis, berdiskusi, bekerja secara kolaboratif, dan melakukan presentasi.Pendapat ini dudukung oleh Schunk (2012) yang menyatakan bahwa model pembelajaran yang melibatkan siswa saling bekerjasama untuk memecahkan suatu masalah sehingga memperoleh konsep-konsep baru terbukti dapat mencegah terjadinya miskonsepsi siswa yang lebih besar.

Model pembelajaran modified inquiry berhasil mencegah untuk tidak terjadinya miskonsepsi siswa pada konsep kesetimbangan kimia, meskipun belum secara total menghilangkan beban miskonsepsi siswa. Beban miskonsepsi yang masih tersisa setelah tindakan pencegahan dengan model pembelajaran modified inquiry dapat dijelaskan sebagai berikut: (1) Hasil analisis terhadap isian Lembar Kerja Siswa, ditemukan terdapat kelompok siswa yang masih gagal dalam menyusun hipotesis, menganalisis data, dan menarik simpulan. Menyusun hipotesis, menganalisis data, dan menarik simpulan menurut Eggen (1979) adalah diantara tahap-tahap yang harus dilalui dalam pembentukan konsep.Kegagalan dalam tahap-tahap tersebut dapat menjadi penyebab masih adanya miskonsepsi siswa, (2) Pelaksanaan sintaks pembelajaran tidak memberi kesempatan kepada siswa untuk menuliskan non contoh dari konsep-konsep kesetimbangan kimia.Akibatnya, siswa kurang memahami atribut atau ciri-ciri esensial yang terkandung di dalam konsep-konsep kesetimbangan kimia.Siswa tidak dapat membedakan antara contoh konsep, dan bukan konsep sehingga menimbulkan miskonsepsi (Ibrahim, 2012), dan (3) Karakter konsep kesetimbangan kimia yang tidak dapat dilihat dengan kasat mata atau abstrak.Siswa tidak dapat melihat langsung terjadinya pergeseran kesetimbangan, sehingga siswa tidak dapat membedakan konsep dengan bukan konsep melalui pengamatan ciri esensial dari sebuah konsep.Ketika atribut khusus dari konsep kesetimbangan kimia yang diketahui siswa dengankeyakinan yang rendah, maka pemikiran siswa berpeluang untuk kembali mengalami miskonsepsi (Ibrahim, 2012).

\section{Perubahan Hasil Belajar Siswa Sesudah Pembelajaran dengan Model Modified Inquiry}

Pembelajaran konsep kesetimbangan kimia menggunakan model modified inquiry mampu meningkatkan rata-rata nilai pemahaman siswa terhadap konsep-konsep kesetimbangan kimia. Secara deskriptif dengan kriteria ketuntasan minimal (KKM) sebesar 75, maka pada kelas XI IPA 1 terdapat 15 (lima belas) siswa dari 32 siswa yang tuntas atau $47 \%$. Pada kelas XI IPA 3 terdapat 7 (tujuh) siswa dari 30 siswa yang tuntas atau $23 \%$.

Analisis secara inferensial menggunakan t-Test satu arah seperti pada Tabel 3.

Tabel3Hasilt-Test BedaRata-rata Pemahaman Konsep Kesetimbangan Kimia Sebelum dan Sesudah Pembelajaran

\begin{tabular}{|c|c|c|c|c|c|}
\hline No. & Kelas & df & $t_{\text {hitung }}$ & $\begin{array}{c}t_{\text {tabel }} \\
\text { uji satu arah }\end{array}$ & p-value \\
\hline 1. & XI IPA 1 & 31 & 21,175 & 1,697 & 0,000 \\
\hline 2. & XI IPA 3 & 29 & 19,133 & 1,699 & 0,000 \\
\hline
\end{tabular}

Berdasarkan Tabel 1, nilai $\mathrm{p}$-value $/ 2<0,05$ dan nilai $\mathrm{t}$ hitung $>$ nilai $t$ tabel satu arah, maka dapat disimpulkan bahwa rata-rata pemahaman konsep kesetimbangan kimia sesudah pembelajaran meningkat secara 
signifikan. Artinya, pembelajaran menggunakan model modified inquiry terbukti mampu meningkatkan pemahaman siswa terhadap konsep-konsep kesetimbangan kimia.

Temuan ini menunjukkan bahwa pembelajaran dengan model pembelajaran modified inquiry mampu mendorong siswa untuk mencari dan menemukan sendiri berbagai jawaban atas persoalan-persoalan yang dihadapinya. Pembelajaran dengan modified inquiryberhasilmelatih siswa cara berfikir yang ilmiah. Selain itu, pembelajaran modified inquiry yang menekankan pada keterampilan proses membuat pembelajaran menjadi lebih bermakna bagi siswa (Sagala, 2012). Informasi baru yang diperoleh selama proses pembelajaran dihubungkan dengan struktur pengertian yang sudah dipunyai seseorang yang sedang belajar. Hasil proses pembelajaran itu membuat pemahaman siswa terhadap konsep yang dipelajari menjadi lebih baik.

Kunci keberhasilan model modified inquiry yang mengacu kepada sintaks yang dibuat oleh Arends (2012), yaitu penekanannya pada hakikat interaksi sosial dari siswa. Model pembelajaran yang menekankan pada interaksi sosial siswa dengan teman sebaya yang lebih mampu/pintar. Menurut teori belajar konstruktivis dari Vygotsky, siswa belajar konsepkonsep dalam zona perkembangan terdekat atau zone of proximal develop-ment (zpd) mereka. Siswa mencapai zona perkembangan potensialnya dengan bantuan guru/orang dewasa atau teman yang lebih pintar dengan melakukan scaffolding. Melalui scaffolding, siswa menerimasejumlah besar bantuan dari guru/orang dewasa atau teman sebaya yang lebih pintar. Secara bertahap kemudian bantuan tersebut dikurangi dengan memberikan kesempatan kepada siswa untuk mengambil alih tanggung jawab sesudah siswa mampu mengerjakan tugas sendiri.

\section{E. Faktor Penyebab Miskonsepsi Siswa pada Konsep Kesetimbangan Kimia}

Berdasarkan hasil kuesioner siswa yangmengalami miskonsepsi pada posttest 1 , diperolehinformasi tentang intensitas faktor penyebab miskonsepsi yang meliputi faktor pemikiran siswa sendiri, faktor buku/ sumber belajar, dan faktor cara mengajar guru.Faktor pemikiran siswa sendiri menempati urutan pertama diikuti oleh faktor buku/sumber belajar dan faktor cara mengajar menempati urutan terakhir.Pemikiran siswa sendiri menjadi faktor penyebab terjadinya miskonsepsi siswa yang dominan karena siswa masih dalam proses belajar, pemikiran siswa terus mengalami perubahan struktur konseptual. Terjadinya miskonsepsi akibat pemikiran siswa sendiri ini disebabkan oleh beberapa hal, yaitu: (1) prakonsepsi atau konsep awal siswayangdibentuk sebelum siswa mendapatkan pelajaran formal tentang konsep kesetimbangan kimia, (2) pemikiran asosiatif siswaterhadap istilah-istilah sehari-hari, (3) pemikiran humanistik yangmemandang semua benda di sekitarnya sesuai dengan nalurinya sebagai manusia atau bersifat manusiawi, (4) penalaran (reasoning) yang tidak lengkap atau salahakibat dari kesalahan logika berpikir yang digunakan untuk menarik simpulan, (5) intuisi yang salahakibat kegiatan berpikir yang didasarkan pada perasaan yang muncul secara tiba-tiba tanpa melalui penalaran, (6) tahap perkembangan kognitif siswa yang tidak sesuai dengan materi pelajaran yang diajarkan kepada siswa, (7) kecerdasandan bakat siswasangat berpengaruh terhadap kecepatan dan ketepatan siswa dalam memahami materi ajar, khususnya menghubungkan antarkonsep, dan (8) minat belajarmemiliki pengaruh terhadap perhatian yang lebih besar padamateri ajar yang dipelajari (Suparno, 2005).

Miskonsepsi karena buku teks pelajaran terjadikarena penjelasan yang keliru dalam buku tersebut, kesalahan penulisan yang tidak diikuti dengan ralat, penggunaan bahasa yang terlalu tinggi untuk level siswa yang dituju, banyak siswa yang membaca buku teks sepotong-sepotong sehingga memberikan pemahaman yang tidak utuh dan benar, pemberian ilustrasi gambar yang diambil dalam kehidupan sehari-hari yang tidak sesuai dengan makna konsep yang sesungguhnya,penggunaan gambar kartun yang sering mengandung miskonsepsi.Sebagai contoh, pada sebuah buku teks kimia SMA kelas XI dipaparkan ilustrasi gambar untuk menganalogikan keadaan kesetimbangandinamis berupa permainan jungkatjungkit mengakibatkan terjadinya miskonsepsi karena keadaan kesetimbangan dinamis tercapai jika beratnya sama.Miskonsepsi karena guruterjadi karena guru tidak menguasai materi secara utuhdan benar (tidak memiliki kompetensi profesional dan pedagogik), guru tidak berlatar belakang sarjana bidang ilmu yang diajarkan (misal sarjana pendidikan matematika tetapi mengajar kimia), guru tidak melakukan aktivitas untuk mendeteksi terjadinya miskonsepsi siswa secara dini dan guru tidak menjalin hubungan baik dengan siswa sehingga siswa mengalami kesulitan dalam pemahaman suatu konsep tidak berani bertanya.

\section{PENUTUP}

\section{Simpulan}

Tindakan pencegahanmiskonsepsi siswadengan model pembelajaranmodified inquiry pada konsep kesetimbangan kimia menghasilkan simpulan bahwa tindakan pencegahan telah berhasil menekan terjadinya miskonsepsi siswa, meskipun masih menyisakan sejumlah siswa miskonsepsi.

\section{Saran}

1. Guru kimia perlu memperhatikan prakonsepsi siswa sebelum melaksanakan kegiatan pembelajaran agar 
potensi terjadinya miskonsepsi dapat diketahui secara dini.

2. Tindakan pencegahan dengan model pembelajaran modified inquiry untuk mencegah terjadinya miskonsepsi siswa perlu mengintegrasikan keterampilan psiko-motorik, perilaku karakter, keterampilan sosial, dan melatihkankan siswa memberi contoh konsep dan bukan konsep agar memberikan dampak yang maksimal.

3. Beban miskonsepsi yang masih tersisa setelah pembelajaran dengan model pembelajaran modified inquiry perlu diremediasi untuk mereduksi beban miskonsepsi pada setiap siswa.

\section{DAFTAR PUSTAKA}

Akbas, Yavuz. 2012. "High School 9th Grade Students' Understanding Level and Misconceptions AboutTemperature and Factors Affecting It". Educational Research And Reviews. 7(30): 670-677.

Arends, Richard I. 2012. Learning to Teach. $9^{\text {st }}$ Edition. New York: McGraw-Hill.

Arends, Richard I. 1997. Classroom Instruction and Managemen. New York: MC Grew-Hiil.

Arslan, Harika Ozge, Ceyhan Cigdemoglu, dan Christine Moseley, 2012. "A Three-Tier Diagnostic Test to Assess Pre-Service Teachers' Misconceptions about Global Warming, Greenhouse Effect, Ozone Layer Depletion, and Acid Rain", International Journal of Science Education, 34 (11): 1667-1686.

Barke, Hans Dieter,Al Hazaril and Sileshi Yitbarek. 2009. Misconception in Chemistry: Addressing Perception in Chemical Education.Verlag Berlin: Springer.

Barthlow , Michelle J. 2011. "The Effectiveness of Process Oriented Guided Inquiry Learning to Reduce Alternate Conceptions in Secondary Chemistry". Doctoral Dissertation. University of Liberty.

Direktorat Jenderal Manajemen Pendidikan Dasar dan Menengah.2006. Standar Penilaian Untuk Satuan Pendidikan dasar dan Menengah Standar Kompetensi dan Kompetensi dasar SMA/MA.Jakarta: Depdiknas.

Bodner, G.M, 1986. "Constructivism: A Theory of Knowledge". Journal of Chemical Education, 63(10): $1-15$.

Dahar, Ratna Wilis. 2011.Teori-teori Belajar\& Pembelajaran. Jakarta: Erlangga.

Djarwanto, 1991. Statistik Nonparametrik. Yogyakarta: BPFE.

Forgaty, Robin. 1991. The Mindful School: How to Interate The Curicula. USA: Skylight Publishing, Inc

Ibrahim, Muslimin. 2012. Konsep Miskonsepsi dan Cara Mengatasinya. Surabaya: Unesa University Press.

Eggen Paul D, Donald P. Kauchack, and Robert J. Harder. 1979. Strategies for Teacher: Information Processing

Nur, M. 2008. Pengajaran Berpusata kepada Siswa dan Pendekatan Konstruktivisme dalam Pengajaran.
Surabaya: Pusat Sains dan Matematika Sekolah. Universitas Negeri Surabaya.

Teaching Volume 2. Prentice Hall Series in Educational Innovation. Halaman 90-105.

Sagala, Syaiful.2012. Konsep dan Makna Pembelajaran. Bandung: Alfabeta.

Schunk, Dale H. 2012. Learning Theories: An Educational Perspective, $6^{\text {th }}$ Edition, Boston: Pearson Education.

Sudjana. 1996. Metoda Statistik. Bandung: Tarsito.

Sugiyono. 2012. Metode Penelitian Kuntitatif Kualitatif dan $R \& D$. Bandung: Alfabeta.

Suparno, Paul 2005. Miskonsepsi dan Perubahan Konsep Pendidikan Fisika. Jakarta: Grasindo. 